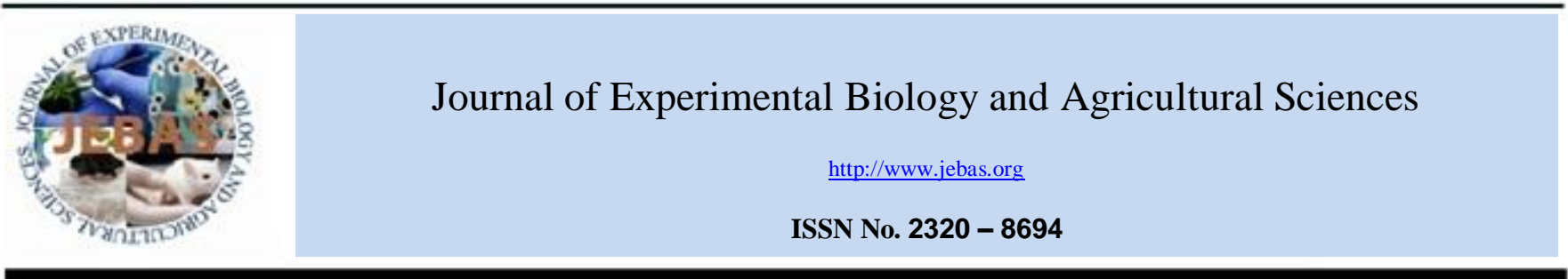

\title{
MARKER BASED ASSESSMENT OF GENETIC DIVERSITY IN NUTMEG (Myristica fragrans Houtt.) USING ISSR PRIMERS
}

\author{
Anu G. Krishnan*, Reshma John, Sible George Varghese
}

Regional Agricultural Research Station, Kerala Agricultural University, Kumarakom, Kottayam, Kerala - 686563, India.

Received - January 01, 2019; Revision - February 14, 2019; Accepted - March 23, 2019

Available Online - April 10, 2019

DOI: http://dx.doi.org/10.18006/2019.7(2).108.116

KEYWORDS
Myristica fragrance
Nutmeg
Genetic diversity
ISSR
Cluster analysis

\begin{abstract}
Inter Simple Sequence Repeats (ISSR) constitute a reliable molecular marker system for genetic diversity analysis among species. The present study was conducted to evaluate genetic diversity / relatedness among superior accessions of Myristica fragrans (Nutmeg) maintained at the germplasm of Regional Agricultural Research Station, Kumarakom, Kerala, India using ISSR markers. Genomic DNA was extracted from 19 superior genotypes of nutmeg. Among the 34 ISSR primers used, only 16 primers developed reproducible banding pattern. The selected primers generated 145 amplified bands, of which 97 were found to be polymorphic. The amplicon size varied between 300 to $1500 \mathrm{bp}$. The polymorphism percentage for the tested primers ranged between $33 \%$ (UBC 860) to 100\% (UBC 852a) with an average value of $65.73 \%$. Among the different primers studied the primer UBC 815 showed the highest PIC value $(0.48)$ and the primer UBC860 provided the lowest value $(0.10)$. The mean value for marker index (MI) observed in this study was 1.62. The Jaccard's similarity coefficient for the genotypes studied varied from 0.565 to 0.939 . The dendrogram derived from UPGMA analysis separated the nineteen nutmeg accessions into two major clusters. The information obtained from this study could be used for further breeding programmes in nutmeg.
\end{abstract}

* Corresponding author

E-mail: anu.gk@kau.in (Anu G. Krishnan)

Peer review under responsibility of Journal of Experimental Biology and Agricultural Sciences.

Production and Hosting by Horizon Publisher India [HPI] (http://www.horizonpublisherindia.in/).

All rights reserved.
All the article published by Journal of Experimental Biology and Agricultural Sciences is licensed under a Creative Commons Attribution-NonCommercial 4.0 International License Based on a work at www.jebas.org.

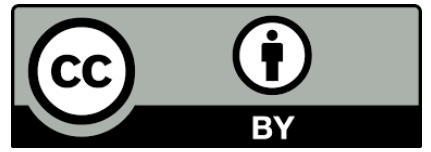




\section{Introduction}

Myristica fragrans Houtt. (Myristicaceae), commonly known as nutmeg, is an evergreen aromatic tree which produces two economically important spices, namely nutmeg seed and mace. Nutmeg is originated from spice islands of Indonesia (Leela, 2008) It is a tropical tree and commonly available in Malaysia, India, Indonesia and South East of Asia (Al-Rawi et al., 2011). The dried kernel of broadly ovoid seed of the nutmeg is known for its aromatic properties (Tajuddin et al., 2003). The nutmeg as a spice is used mainly in food processing industry and the mace is used in savory dishes (Leela, 2008). The seed and mace are widely used in pharmaceutical industries. Various researchers have narrated the anti oxidant properties of nutmeg (Madsen \& Berteldsen, 1995; Lagouri \& Boskou, 1995). M. fragrans is considered as a source of medicinally active compounds with various pharmacological effects like anti-oxidant, anti-cancerous, anti-diabetic, anti-depressant and hypocholesterolemic (Asgarpanah \& Kazemivash, 2012). Myristicin extracted from nutmeg is reported to have hepatoprotective effects (Morita et al., 2003). The nutmeg is traditionally used for treating digestive disorders and kidney ailments. South East Asians use this for treating fever, headaches and bronchial problems. The Chinese consider this as an aphrodisiac (Leela, 2008). The nutmeg oil also has many therapeutic properties and is used in Ayurveda and Homeopathic treatments. Fruit powder is used (3-6gms) in Ayurveda for Atisara, Grahini, Chardi, Mukhroga, Pinasa, Rasa, Svasa and Sukrameha (Tripathi \& Dwivedi, 2015). The fruit processes several pharmacological properties viz. stimulant, narcotic, carminative, astringent, aphrodisiac, acrid, astringent, sweet, bitter, thermogenic, diuretic, hypolipidaemic, antithrombotic, anti-platelet aggregation, antifungal, anti-inflammatory, anodyne, vulnerary, alternate, stomachic, laxative, carminative, digestive, anthelmintic, cordiotonic, aphrodisiac, antiseptic, febrifuge, depurative and tonic (Muchtaridi et al.,2010; Bamidele et al.,2011; Shafiei et al., 2012) According to Krishnamoorthy \& Rema (2001) the nutmeg oil is used externally as a stimulant.

In India the area under nutmeg cultivation is showing an increasing trend, especially in the southern region owing to the high price of nutmeg and mace prevailing in international markets. In India, it is grown throughout Kerala, parts of TamilNadu, Karnataka, Goa, Assam and Andaman and Nicobar Islands (Thangaselvabai et al.,2011 ).

According to Khan et al. (2015) genetic diversity analysis involving molecular markers are useful for understanding the genomic constitution, genes responsible for important traits and germplasm conservation. Ni et al (2002) opined that genetic diversity analysis is helpful for developing genetically unique germplasm which compliments existing cultivars. ISSR markers are simple, reproducible and inexpensive. They are widely used for analysing genetic diversity between closely related cultivars (Gonzalez et al., 2002), molecular characterisation of germplasm (Charters \& Wilkinson, 2000), phylogenetic studies (Ajibade et al., 2000), marker assisted selection in plant breeding and genome mapping (Reddy et al., 2002). It also provides information about markers linked to agronomic traits, and disease resistance (Ratnaparkhe et al., 1998).

Variability is observed in the growth rate, productivity, size and shape of leaf, flower, fruit and seed in nutmeg (Krishnamoorthi, 1996; Haldankar et al., 2004). Sheeja et al. (2006) reported molecular variation between clonal and seedling progenies of nutmeg using RAPD markers. Authors have already reported (Krishnan et al., 2017) the diversity analysis using RAPD primers in nutmeg The aim of the present study was to assess the genetic variability and to characterise the germplasm of $M$. fragrans using ISSR markers.

\section{Materials and methods}

\subsection{Plant sample collection}

The ISSR analysis was conducted on nineteen promising nutmeg accessions conserved at the Regional Agricultural Research Station, Kumarakom, Kerala, India (Table 1). Among these accessions 18 genotypes were collected from different locations

Table 1 Selected nutmeg accessions and their site of collection for genetic diversity analysis using ISSR markers

\begin{tabular}{|c|c|c|}
\hline Sl No. & Genotypes/Accession & Place of Collection \\
\hline 1 & ACC1 & $\begin{array}{l}\text { IISR Viswasree } \\
\text { (a released variety) }\end{array}$ \\
\hline 2 & $\mathrm{ACC} 2$ & Kadapoor \\
\hline 3 & $\mathrm{ACC} 3$ & Vaikom \\
\hline 4 & ACC4 & Vaikom \\
\hline 5 & ACC5 & Piravom \\
\hline 6 & ACC6 & Piravom \\
\hline 7 & ACC17 & Piravom \\
\hline 8 & ACC7 & Chengalam \\
\hline 9 & ACC 8 & Chengalam \\
\hline 10 & ACC9 & Arunootimangalam \\
\hline 11 & $\mathrm{ACC} 21$ & Arunootimangalam \\
\hline 12 & ACC22 & Arunootimangalam \\
\hline 13 & ACC12 & Poovarani \\
\hline 14 & ACC19 & Poovarani \\
\hline 15 & ACC13 & Elikulam \\
\hline 16 & ACC14 & Chengalam \\
\hline 17 & ACC20 & Pinakanad \\
\hline 18 & ACC15 & Kanjirappally \\
\hline 19 & ACC11 & Kanjirapally \\
\hline
\end{tabular}


of Kottayam district in Kerala and one was a released variety IISR Viswasree,. The local genotypes were selected based on their fruit characters and yield. Emerging pale green leaves collected from the selected genotypes were wrapped in aluminium foil and kept in ice boxes until reaching the laboratory. Then these were plunged in liquid nitrogen and stored at $-80{ }^{\circ} \mathrm{C}$ until DNA extraction.

\subsection{DNA extraction}

The genomic DNA extraction was performed using the modified CTAB protocol described by Divyasree et al. (2014). For this protocol $0.2 \mathrm{~g}$ of fresh leaf tissue was ground in a preheated $\left(60{ }^{\circ} \mathrm{C}\right)$ mortar and pestle using $1 \mathrm{ml}$ extraction buffer, $50 \mu 1 \beta$-mercaptoethanol and a nip of PVP. Further, the ground material was subjected to incubation in a water bath at $60^{\circ} \mathrm{C}$ for 30 minutes, with mixing at intervals. This was centrifuged at $7200 \mathrm{rpm}$ for 10 minutes at $25^{\circ} \mathrm{C}$ after adding equal volume of Chloroform: Isoamyl alcohol (24:1). After that, the aqueous phase on the top was pipetted in to a sterile $1.5 \mathrm{ml}$ tube. This was mixed with $2 / 3 \mathrm{rd}$ volume of ice cold isopropanol. The tube was inverted gently to facilitate DNA precipitation. Then centrifugation carried out at $7200 \mathrm{rpm}$ at $25{ }^{\circ} \mathrm{C}$ for 3 minutes. $1 \mathrm{ml}$ of wash buffer $(76 \%$ ethanol, $10 \mathrm{mM}$ ammonium acetate) was added to this after discarding supernatant. Then the samples were kept for incubation at room temperature for 20 minutes. Again this was centrifuged at $7200 \mathrm{rpm}$ for 10 minutes at $25^{\circ} \mathrm{C}$. The pellet obtained after discarding the supernatant was dissolved in $30 \mu$ of sterile distilled water. The quantity and quality of DNA were checked with spectrophotometer (Shimadzu) and agarose gel (0.8\%) electrophoresis.

\subsection{ISSR analysis}

PCR amplification was performed in an Agilent Sure Cycler 8800 (Agilent Technologies, USA) using 34 ISSR primers (The University of British Columbia, Canada) as suggested by Sheeja et al. (2008) (Table 2). The reaction mixture contained deionised water $17 \mu \mathrm{L}, T a q$ buffer (10x) $2.5 \mu \mathrm{L}, \mathrm{MgCl}_{2}(25 \mathrm{mM}) 1 \mu \mathrm{L}$, ISSR Primer $(10 \mathrm{pmol} / \mu \mathrm{L}) 2 \mu \mathrm{L}, \mathrm{dNTP} \operatorname{mix}(2.5 \mathrm{mM}$ each $) 1$ $\mu \mathrm{L}, \mathrm{Ta} q$ DNA Polymerase (2 U/ $\mu \mathrm{L}$ ) $0.5 \mu \mathrm{L}$, Template DNA (25 $\mathrm{ng} / \mu \mathrm{L}) 1 \mu \mathrm{L}$ with a final volume of $25 \mu \mathrm{L}$. The PCR programme was designed as follows: initial denaturation of $4 \mathrm{~min}$ at $94^{\circ} \mathrm{C}$; followed by 35 cycles of denaturation for $35 \mathrm{~s}$ at $94^{\circ} \mathrm{C}$, primers annealing for $1 \mathrm{~min}$ at $50-55^{\circ} \mathrm{C}$, and extension for $10 \mathrm{~min}$ at $72^{\circ} \mathrm{C}$, followed by a final extension for $10 \mathrm{~min}$ at $72^{\circ} \mathrm{C}$. Amplified products were size-separated on $2 \%$ agarose gel and documented using a Bio-Rad Gel Documentation System (BioRad Laboratories, Hercules, CA).
Table 2 List of ISSR primers used for the study

Sl. No. Primer Nucleotide sequence

\begin{tabular}{|c|c|c|}
\hline 1 & UBC 807 & 5'-AGAGAGAGAGAGAGAGT-3' \\
\hline 2 & UBC 809 & 5'-AGAGAGAGAGAGAGAGG-3' \\
\hline 3 & UBC 810 & 5'-GAGAGAGAGAGAGAGAT-3' \\
\hline 4 & UBC 812 & 5'-GAGAGAGAGAGAGAGAA-3' \\
\hline 5 & UBC 815 & 5'-СТСТСТСТСТСТСТСТG-3' \\
\hline 6 & UBC 816 & 5'-CACACACACACACACAT-3' \\
\hline 7 & UBC $834 \mathrm{a}$ & 5'-AGAGAGAGAGAGAGAGCT-3' \\
\hline 8 & UBC $834 b$ & 5'-AGAGAGAGAGAGAGAGTT-3' \\
\hline 9 & UBC 835 & 5'-AGAGAGAGAGAGAGAGCC-3' \\
\hline 10 & UBC $836 a$ & 5'-AGAGAGAGAGAGAGAGCA-3' \\
\hline 11 & UBC 838 & 5'-TATATATATATATATAAC-3' \\
\hline 12 & UBC 840a & 5'-GAGAGAGAGAGAGAGACT-3' \\
\hline 13 & UBC $840 \mathrm{~b}$ & 5'-GAGAGAGAGAGAGAGATT-3' \\
\hline 14 & UBC 841a & 5'-GAGAGAGAGAGAGAGACC-3' \\
\hline 15 & UBC $841 b$ & 5'-GAGAGAGAGAGAGAGATC-3' \\
\hline 16 & UBC $842 b$ & 5'-GAGAGAGAGAGAGAGATG-3' \\
\hline 17 & UBC 843a & 5'-СТСТСТСТСТСТСТСТАА-3' \\
\hline 18 & UBC $844 a$ & 5'-СТСТСТСТСТСТСТСТАС-3' \\
\hline 19 & UBC $848 \mathrm{a}$ & 5'-CACACACACACACACAAG-3' \\
\hline 20 & UBC $850 \mathrm{a}$ & 5'-GTGTGTGTGTGTGTGTCC-3' \\
\hline 21 & UBC $852 a$ & 5'-ТСТСТСТСТСТСТСТСАА-3' \\
\hline 22 & UBC 855 & 5'-ACACACACACACACACYT-3' \\
\hline 23 & UBC $857 \mathrm{a}$ & 5'-ACACACACACACACACCG-3' \\
\hline 24 & UBC $857 b$ & 5'-ACACACACACACACACTG-3' \\
\hline 25 & UBC 858 & 5'-TGTGTGTGTGTGTGTGRT-3' \\
\hline 26 & UBC 860 & 5'-TGTGTGTGTGTGTGTGAA-3' \\
\hline 27 & UBC 862 & 5'-AGCAGCAGCAGCAGCAGC-3' \\
\hline 28 & UBC 865 & 5'-CCGCCGCCGCCGCCGCCG-3' \\
\hline 29 & UBC 866 & 5'-СТССТССТССТССТССТС-3' \\
\hline 30 & UBC 868 & 5'-GAAGAAGAAGAAGAAGAA-3' \\
\hline 31 & UBC 872 & 5'-GATAGATAGATAGATA-3', \\
\hline 32 & UBC 873 & 5'-GACAGACAGACAGACA-3' \\
\hline 33 & UBC 874 & 5'-СССТСССТСССТСССТ-3' \\
\hline 34 & TC $10 \mathrm{G}$ & 5'-ТСТСТСТСТСТСТСТCTCTCG-3' \\
\hline
\end{tabular}




\subsection{Data analysis}

The molecular size of the amplicons was estimated based on the relative position of bands with the 100 bp ladder marker which was run along with the amplified product. The amplified bands were scored as present (1) or absent (2). Only those bands which were clear and reproducible were considered for scoring. The percentage of polymorphism was calculated using the binary data generated. The Polymorphism Information Content (PIC) was calculated as PIC $=2 \mathrm{fi}(1-f i)$, where fi is frequency of amplified allele (band present) and (1 - $f i$ ) is frequency of null allele (band absent) for the allele $i$ (Roldan-Ruize et al., 2000). The marker index (MI) was calculated as a product of PIC and number of polymorphic bands per assay unit as explained by Powel et al. (1996). The MI value assesses the overall utility of a marker system. The genetic relationship between selected accessions was analysed using the software programme Numerical Taxonomy and Multivariate Analysis System (NTSYS-pc, Version 2.02e, Exeter Software, NY, USA) (Rohlf, 1998). Jaccard's coefficient of similarity (Jaccard, 1908) was calculated with the SIMQUAL program. These similarity coefficients were used to generate UPGMA (Unweighted Pair Group with Arithmetic Averages) dendrogram using SAHN module of NTSYS-pc (Sneath \& Sokal 1973).

\section{Result and discussion}

Different types of molecular markers have been used in nutmeg for assessing genetic diversity such as RAPD (Sheeja et al., 2006; Krishnan et al., 2017) and ISSR (Sheeja et al., 2013). Inter simple sequence repeat markers are one of the robust tool used to evaluate genetic diversity in agronomically important crops (Brantestam et al., 2004). In this study, 34 ISSR primers were screened for their amplification efficiency in 19 superior accessions of nutmeg. Among them 16 primers generated clear and reproducible banding profile. These ISSR primers yielded 145 amplified bands of which 97 were polymorphic. The number of amplified fragments for each primer ranged from 3 (UBC 860) to 13 (UBC 840A and UBC 810 ) with a mean of 8.5 bands per primer which varied in size from 300 to $1500 \mathrm{bp}$. The percentage of polymorphism among the primers studied showed an average value of $65.73 \%$ and it varied between $33 \%$ (UBC 860) to $100 \%$ (UBC 852a). The highest number of polymorphic bands was yielded by the primers UBC 857b, UBC 807 and UBC 852a (Figure 1). Sheeja et al. (2013) reported that 16 ISSR primers produced 262 bands with a polymorphism of $97.3 \%$ in seven Myristica sp., two of its related genera and one unidentified species. In a related study with eight accessions of Cinnamomum tamala, Gawari et al. (2016) obtained an average polymorphism of $86.3 \%$ for 3 ISSR markers. The rate of polymorphism obtained in this study was higher when compared to ISSR analysis in Garcinia xanthochymas where polymorphism was only $21.25 \%$ (Anerao et al., 2016)

The discriminatory power of ISSR primers for genetic relationship analysis was evaluated using polymorphic information content (PIC), and marker index. In the present study the PIC value of 16 ISSR primers ranged from 0.10 to 0.48 with an average of 0.28 , which indicate that these ISSR markers are highly informative (Table 3). The most informative marker in this study was UBC 815 since it recorded highest PIC value (0.48). Thimmappaiah et al. (2009)

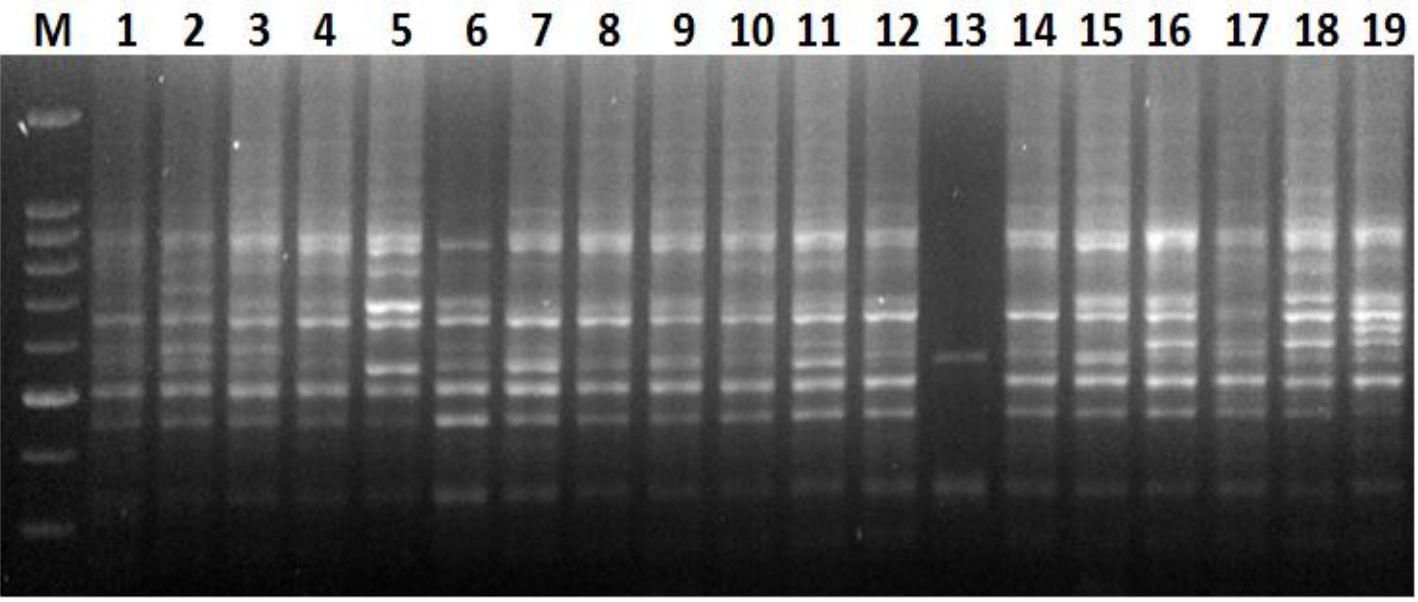

Figure 1 ISSR profiling of selected Nutmeg genotypes using UBC807. Lane M: 100bp DNA Ladder; Lane 1: Acc. 1; Lane2: Acc. 2; Lane 3:Acc.3; Lane 4 Acc. 4; Lane 5 : Acc.5; Lane 6 : Acc.6; Lane 7 : Acc.17; Lane 8: Acc.7; Lane 9: Acc.8; Lane 10: Acc.9; Lane 11: Acc.21; Lane 12: Acc.22; Lane 13: Acc.12; Lane 14: Acc.19; Lane 15: Acc.13; Lane 16: Acc.14; Lane 17: Acc.20; Lane 18: Acc.15; Lane 19: Acc.11. 
Table 3 ISSR data obtained with 16 primers analysed on 19 accessions of M. fragrans.

\begin{tabular}{|c|c|c|c|c|c|}
\hline Primer & Total number of bands & $\begin{array}{c}\text { Percentage of } \\
\text { polymorphic bands }\end{array}$ & $\begin{array}{c}\text { Percentage of } \\
\text { monomorphic bands }\end{array}$ & PIC & MI \\
\hline UBC $840 \mathrm{~A}$ & 13 & 53.85 & 46.15 & 0.34 & 2.35 \\
\hline UBC 860 & 3 & 33.00 & 66.00 & 0.10 & 0.10 \\
\hline UBC 844A & 9 & 55.00 & 45.00 & 0.26 & 1.27 \\
\hline UBC 807 & 11 & 81.81 & 18.18 & 0.24 & 2.20 \\
\hline UBC 858 & 7 & 85.71 & 14.28 & 0.22 & 1.29 \\
\hline UBC 840B & 10 & 70.00 & 30.00 & 0.29 & 2.02 \\
\hline UBC 852A & 9 & 100.00 & 0.00 & 0.20 & 1.79 \\
\hline UBC 842B & 5 & 80.00 & 20.00 & 0.30 & 1.20 \\
\hline UBC 857B & 10 & 90.00 & 10.00 & 0.24 & 2.13 \\
\hline UBC $850 \mathrm{~A}$ & 6 & 50.00 & 50.00 & 0.22 & 0.66 \\
\hline UBC 855 & 9 & 55.00 & 44.00 & 0.34 & 1.69 \\
\hline UBC 812 & 10 & 50.00 & 50.00 & 0.40 & 2.01 \\
\hline TC-10 & 6 & 83.33 & 16.66 & 0.26 & 1.29 \\
\hline UBC 815 & 6 & 33.33 & 66.66 & 0.48 & 1.92 \\
\hline UBC 848 & 10 & 60.00 & 40.00 & 0.27 & 1.59 \\
\hline UBC 834A & 8 & 75.00 & 25.00 & 0.30 & 1.78 \\
\hline UBC 810 & 13 & 61.50 & 38.50 & 0.29 & 2.29 \\
\hline Total & 145 & & & & \\
\hline Average & 8.5 & $65.73 \%$ & $36.27 \%$ & 0.28 & 1.62 \\
\hline
\end{tabular}

obtained similar results in Cashew (Anacardium occidentale L.) where the PIC value varied from 0.180 to 0.419 with an average of 0.295 using 10 ISSR primers. Sheeja et al. (2013) observed an average PIC value of 0.35 for 16 ISSR primers in Myristica sp. and related genera. The marker index (MI) calculated for the 16 primers employed in the present investigation ranged from 0.10 to 2.35 with a mean of 1.62 (Table 3). MI reflects the efficiency of marker to analyse a large number of bands, rather than level of polymorphism detected (Powell et al., 1996).

The Jaccard's similarity co-efficient ranged between 0.565 and 0.939 (Table 4) revealing a moderate level of genetic diversity among the accessions studied. The accessions ACC7 and
ACC11 showed most distinct genetic relationship with the lowest similarity index (0.565) whereas the accessions ACC22 and ACC19 were closer in their genetic makeup with highest similarity index (0.939). Jaccard's similarity coefficient ranged from 0.55 to 1.00 in 22 Castor (Ricinus communis L.) genotypes using 21 ISSR primers (Gajera et al., 2010). The genetic similarity coefficient of 48 okras ranged from 0.6558 to 0.9935 using 22 ISSR markers (Yuan et al., 2015).

The data generated was used to estimate genetic similarity for pair wise accessions based on Jaccard's similarity coefficient. The UPGMA dendrogram constructed based on Jaccard's similarity coefficient clustered the 19 genotypes into two major clusters at a coefficient value of 0.62 (Figure 2). In the 


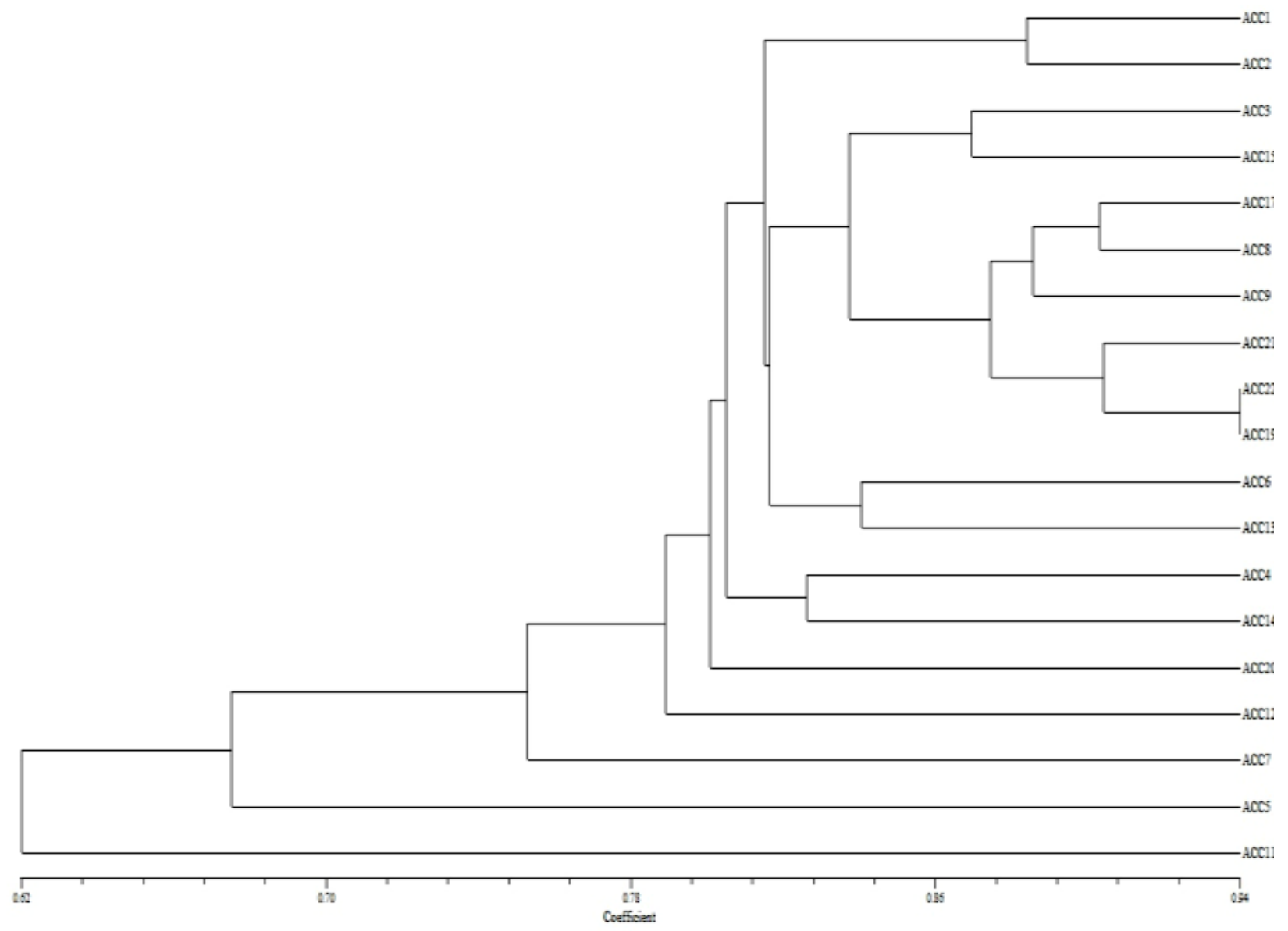

Figure 2 Dendrogram obtained from 19 accessions of Nutmeg with UPGMA based on Jaccard's coefficient

dendrogram ACC 11 was most genetically dissimilar and was separated from all other accessions. The remaining accessions were again divided into 2 with accession ACC 5 alone forming a separate category. The accessions ACC19 \& ACC22 showed maximum amount of similarity.

Assessment of genetic variation is essential for developing high yielding varieties (Kumar et al., 2015). Hence the information generated under this study about the variability of nutmeg trees in Kerala will be useful for further crop improvement programme of nutmeg.

In conclusion, the current study demonstrated the genetic diversity existed between the 19 superior accessions of nutmeg maintained in farm of RARS, using ISSR markers. Predominance of duplicates is common in germplasm banks.
They can be eliminated by molecular characterization of the accessions and thereby reducing the cost of maintenance of redundant in clonal repositories.

\section{Acknowledgement}

The authors wish to express their sincere gratitude to the Director of Research, (Kerala Agricultural University), and the Associate Director of Research, (RARS, Kumarakom) for providing all essential resources for carrying out this research work. The financial assistance from the $13^{\text {th }}$ Finance Commission Grant- in- aid scheme is greatly acknowledged.

\section{Conflict of Interest}

Authors hereby declare no conflict of interest. 
Table 4 Jaccard's co-efficient of similarity between 19 nutmeg accessions based on ISSR data.

\begin{tabular}{|c|c|c|c|c|c|c|c|c|c|c|c|c|c|c|c|c|c|c|c|}
\hline & ACC1 & ACC2 & ACC3 & ACC4 & ACC5 & ACC6 & $\mathrm{ACC} 17$ & ACC7 & ACC8 & ACC9 & $\mathrm{ACC} 21$ & $\mathrm{ACC} 22$ & $\mathrm{ACC} 12$ & ACC19 & $\mathrm{ACC} 13$ & ACC14 & ACC20 & ACC15 & ACC 11 \\
\hline $\mathrm{ACC} 1$ & 1.000 & & & & & & & & & & & & & & & & & & \\
\hline $\mathrm{ACC} 2$ & 0.883 & 1.000 & & & & & & & & & & & & & & & & & \\
\hline ACC 3 & 0.827 & 0.848 & 1.000 & & & & & & & & & & & & & & & & \\
\hline $\mathrm{ACC} 4$ & 0.785 & 0.801 & 0.858 & 1.000 & & & & & & & & & & & & & & & \\
\hline ACC5 & 0.611 & 0.635 & 0.693 & 0.680 & 1.000 & & & & & & & & & & & & & & \\
\hline ACC6 & 0.835 & 0.836 & 0.807 & 0.750 & 0.650 & 1.000 & & & & & & & & & & & & & \\
\hline ACC17 & 0.793 & 0.835 & 0.848 & 0.822 & 0.679 & 0.852 & 1.000 & & & & & & & & & & & & \\
\hline $\mathrm{ACC} 7$ & 0.762 & 0.770 & 0.725 & 0.725 & 0.689 & 0.763 & 0.788 & 1.000 & & & & & & & & & & & \\
\hline ACC 8 & 0.824 & 0.867 & 0.840 & 0.813 & 0.644 & 0.826 & 0.902 & 0.779 & 1.000 & & & & & & & & & & \\
\hline ACC 9 & 0.818 & 0.860 & 0.876 & 0.821 & 0.677 & 0.798 & 0.868 & 0.772 & 0.902 & 1.000 & & & & & & & & & \\
\hline $\mathrm{ACC} 21$ & 0.779 & 0.821 & 0.848 & 0.796 & 0.705 & 0.815 & 0.882 & 0.735 & 0.874 & 0.881 & 1.000 & & & & & & & & \\
\hline ACC22 & 0.774 & 0.816 & 0.850 & 0.803 & 0.674 & 0.823 & 0.876 & 0.747 & 0.854 & 0.861 & 0.904 & 1.000 & & & & & & & \\
\hline $\mathrm{ACC} 12$ & 0.739 & 0.768 & 0.770 & 0.705 & 0.662 & 0.789 & 0.816 & 0.707 & 0.807 & 0.815 & 0.830 & 0.824 & 1.000 & & & & & & \\
\hline ACC19 & 0.785 & 0.841 & 0.841 & 0.801 & 0.672 & 0.792 & 0.861 & 0.754 & 0.881 & 0.888 & 0.903 & 0.939 & 0.850 & 1.000 & & & & & \\
\hline $\mathrm{ACC} 13$ & 0.744 & 0.815 & 0.800 & 0.748 & 0.654 & 0.8391 & 0.836 & 0.738 & 0.884 & 0.835 & 0.822 & 0.801 & 0.795 & 0.828 & 1.000 & & & & \\
\hline ACC14 & 0.794 & 0.837 & 0.817 & 0.824 & 0.730 & 0.833 & 0.858 & 0.748 & 0.796 & 0.803 & 0.816 & 0.812 & 0.791 & 0.797 & 0.770 & 1.000 & & & \\
\hline ACC20 & 0.792 & 0.822 & 0.802 & 0.743 & 0.662 & 0.793 & 0.816 & 0.746 & 0.781 & 0.828 & 0.816 & 0.851 & 0.776 & 0.822 & 0.743 & 0.818 & 1.000 & & \\
\hline ACC15 & 0.745 & 0.800 & 0.868 & 0.787 & 0.708 & 0.740 & 0.820 & 0.752 & 0.838 & 0.819 & 0.807 & 0.827 & 0.730 & 0.813 & 0.774 & 0.757 & 0.755 & 1.000 & \\
\hline ACC11 & 0.578 & 0.625 & 0.650 & 0.598 & 0.604 & 0.603 & 0.647 & 0.565 & 0.647 & 0.622 & 0.653 & 0.628 & 0.583 & 0.617 & 0.626 & 0.632 & 0.580 & 0.632 & 1.000 \\
\hline
\end{tabular}

Journal of Experimental Biology and Agricultural Sciences

http://www.jebas.org 


\section{References}

Ajibade S, Weeden N, Chite S (2000) Inter simple sequence repeat analysis of genetic relationships in the genus Vigna. Euphytica 111:47-55.

Al-Rawi SS, Ibrahim AH, Rahman NNNA, Nama MMB, Abdul Majid AMS, Kadir MOA (2011) The effect of supercritical fluid extraction parameters on the nutmeg oil extraction and its cytotoxic and antiangiogenic properties. Procedia Food Science 1:1946-1952.

Anerao JS, Jha V, Korgaonkar L, Devi SP, Desai N (2016) Disserting genetic diversity in garcinia xanthochymus using ISSR and RAPD markers. Journal of Plant Breed and Genetics 04: 69-76.

Asgarpanah J, Kazemivash N (2012) Phytochemistry and pharmacologic properties of Myristicafragrans Houtt.: A review. African Journal of Biotechnology 11:12787-12793.

Bamidele O, Akinnuga AM, Alagbonsi IA, Ojo OA, Olorunfemi JO, Akuyuma MA (2011) Effect of ethanolic extract of Myristica fragrans Houtt. (Nutmug) on some heamotological indices in albino rats. International Journal of Medicine and Medical Sciences $3: 215-118$.

Brantestam AK, Bothmer RV, Dayteg C, Rashal I, Tuvesson S, Weibull J (2004) Inter simple sequence repeat analysis of genetic diversity and relationships in cultivated barley of Nordic and Baltic origin. Hereditas 141:186-187.

Charters Y, Wilkinson M (2000) The use of self-pollinated progenies as 'in-groups' for the genetic characterization of cocoa germplasm. Theorical and Applied Genetics 100:160-166.

Divyasree P, Lokesh KA, Lidiya John P, Tintu Joy, Teena Ramachandran V, Anu Thomas Muttakulath, Manila TM, Sandhya Rajan VTK, Mathew D (2014) A simplified protocol for the recovery of high quality DNA from nutmeg. Journal of Tropical Agriculture $52: 79-85$.

Gajera BB, Kumar N, Singh A S, Punvar B S, Ravikiran R, Subhash N, Jadeja G (2010) Assessment of genetic diversity in castor (Ricinus communis L.) using RAPD and ISSR markers. Industrial Crops Products $32: 491-498$.

Gawari G, Bhandari U, Naik G, Haider ZS, Chauhan (2016) Genetic diversity in Cinnamomum tamala Nees. Accessions through DNA fingerprinting using molecular markers. Indian Journal of Agricultural Research $50: 446-450$.
González A, Coulson A, Brettell R (2002) Development of DNA markers (ISSRs) in mango. Acta Horticulturae 575: 139-143.

Haldankar PM, Nagwekar DD, Khandekar RG (2004) Variability in nutmeg. Spice India 17: 9-12.

Jaccard P (1908) Nouvellesrecherchessur la distribution florale. Bulletin de la Société vaudoise des sciences naturelles 44: 223-270.

Khan MK, Pandey A, Thomas G, Akkaya MS, Kayis SA, Ozsensoy Y, Hamurcu M, Gezgin S, Topal A, Hakki EE (2015) Genetic diversity and population structure of wheat in India and Turkey. AoB Plants 7: plv083.

Krishnamoorthy B (1996) Variability in nutmeg. Spice India 9:18-21.

Krishnamoorthy B, Rema J (2001) Nutmeg and Mace. In: Peter K V, editor. Handbook of herbs and spices, Vol. 1, Rev. Edn. Woodhead Publishing Ltd, Cambridge, England, Pp. 238-248.

Krishnan AG, John R, Cyriac A, Sible GV (2017) Estimation of genetic diversity in nutmeg (Myristica fragrans Houtt.) selections using RAPD markers. International Journal of Plant Sciences12:102-107.

Kumar R, Kumar M, Dogra RK, Bharat NK (2015) Variability and character association studies in garden pea (Pisum sativum var. hortense L.) during winter season at mid hills of Himachal Pradesh. Legume Research 38: 164-168.

Lagouri V, Boskou D (1995) Screening for antioxidant activity of essential oils obtained from spices. In: Charalambos G (Ed.) Food Flavors: Generation, Analysis and process influence, Amsterdam, Elsevier, Pp. 869-879.

Leela NK (2008) Nutmeg and Mace. In: Parthasarathy V.A, Chempakam B, Zacharia JT (ed) Chemistry of Spices, Cab International, UK, Pp 165-189.

Madsen LH, Bertelsen G (1995) Spices as antioxidants. Trends in Food Science and Technology 6: 271-277.

Morita T, Jinno K, Kawagishi H, Arimoto Y, Suganuma H, Inakuma T, Sugiyama K (2003) Hepatoprotective effect of myristicin from nutmeg (Myristica fragrans) on lipopolysaccharide/d-galactosamine-induced liver injury. Journal of Agricultural and Food Chemistry 51: 1560-1565.

Muchtaridi, Subarnas A, Apriyantono A, Mustarichie R (2010) Identification of Compounds in the Essential Oil of Nutmeg Seeds 
(Myristica fragrans Houtt.) that Inhibit Locomotor. Activity in Mice. International Journal of Molecular Sciences 11: 4771- 4781.

Ni J, Colowit PM, Mackill DJ (2002) Evaluation of genetic diversity in rice subspecies using microsatellite markers. Crop Science 42: 601-607.

Powell W, Morganate M, Andre C, Hanafey M, Vogel J, Tingey S, Rafalski A (1996) The comparison of RFLP, RAPD, AFLP and SSR (microsatellite) markers for germplasm analysis. Molecular Breeding 2 : 225-238.

Ratnaparkhe M, Tekeoglu M, Muehlbauer F (1998) Inter-simple sequence- repeat (ISSR) polymorphisms are useful for finding markers associated with disease resistance gene clusters. Theoretical and Applied Genetics 97:515-519.

Reddy MP, Sarla N, Siddiq E (2002) Inter simple sequence repeat (ISSR) polymorphism and its application in plant breeding. Euphytica128:9-17.

Rohlf FJ (1998) NTSys-pc: numerical taxonomy and multivariate analysis system, version 2.02a.Exter Publications, Setauket, New York, U.S.A.

Roldan-Ruiz I, Calsyn E, Gilliand TJ, Coll R, van Eijk MJT, De Loose M (2000) Estimating genetic conformity between related ryegrass (Lolium) varieties 2. AFLP characterization. Molecular Breeding 6: 593-602.

Shafiei Z, Shuhairi NN, Md Fazly Shah Yap N, Harry Sibungkil CA, Latip J (2012) Antibacterial activity of Myristica fragrans against oral pathogens. Evidence-based Complementary and Alternative Medicine 2012, [825362]. https://doi.org/10.1155/2012/825362.

Sheeja TE, Rajesh Y, Krishnamoorthy B, Parthasarathy VA (2008) Optimization of DNA isolation and PCR parameters in
Myristica sp. and related genera for RAPD and ISSR analysis. Journal of Spices and Aromatic Crops 17: 91-97.

Sheeja TE, RajeshY, Krishnamoorthy B, Parthasarathy VA (2006) DNA polymorphism in clonal and seedling progenies of an elite nutmeg by RAPD. Journal of Plantation Crops 34: 558-561.

Sheeja TE, Sabeesh C, Shabna OV, Shalini RS, Krishnamoorthy B (2013) Genetic diversity analysis of Myristica and related genera using RAPD and ISSR markers. Journal of Spices and Aromatic Crops 22: 38-46.

Sneath PHA, Sokal RR (1973) Numerical taxonomy the principles and practice of numerical classification. Freeman WH, San Francisco, California, U.S.A Pp. 573.

Tajuddin Ahmad S, Latif A, Qasmi IA (2003) Aphrodisiac activity of $50 \%$ ethanolic extracts of Myristica fragrans Houtt.(nutmeg) and Syzygium aromaticum (L) Merr. \& Perry. (clove) in male mice: a comparative study. BMC Complementary and Alternative Medicine 3: 6-10.

Thangaselvabai T, Sudha KR, Selvakumar T, Balakumbahan (2011) Nutmeg (Myristica fragrans Houtt) - the twin spice - a review. Agricultural Reviews 3: 283 - 293.

Thimmappaiah, Santhosh WG, Shobha D, Melwyn GS (2009) Assessment of genetic diversity in cashew germplasm using RAPD and ISSR markers. Scientia Horticulturae 120: 411-417.

Tripathi IP, Dwivedi N (2015) Pharmacognostical standardization of nutmeg seeds (myristica fragrans houtt.) - a traditional medicine. International Journal of Pharmaseutical Sciences and Research 6: 3096-3102.

Yuan CY, Wang P, Chen PP, Xiao WJ, Zhang C, Hu S (2015) Genetic diversity revealed by morphological traits and ISSR markers in 48 okras (Abelmoschus escullentus L.). Physiology and Molecular Biology of Plants 21: 359-364. 